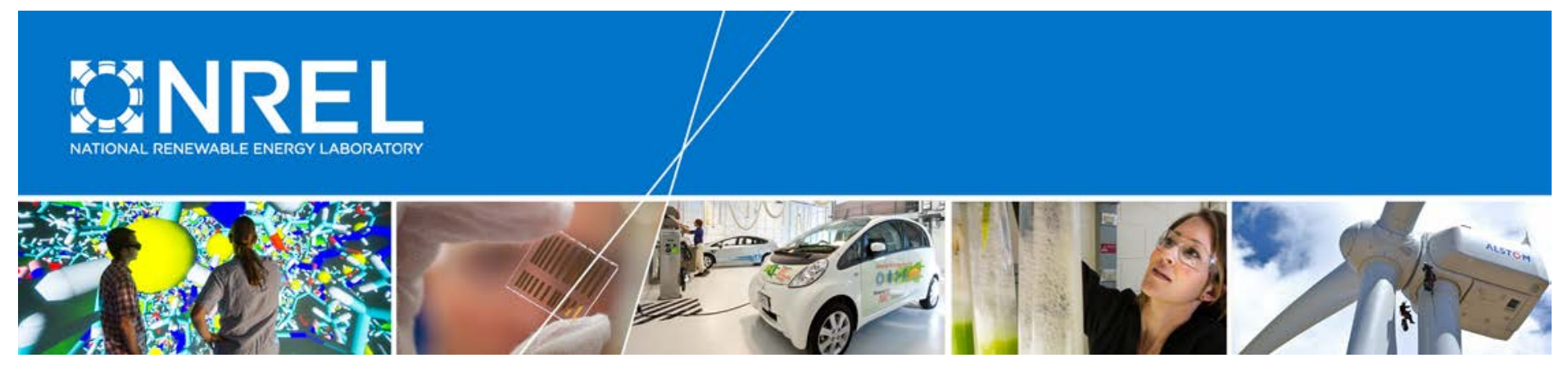

\title{
Transmission Challenges and Best Practices for Cost-Effective Renewable Energy Delivery across State and Provincial Boundaries
}

David Hurlbut, Ella Zhou, Lori Bird, and Qin Wang National Renewable Energy Laboratory

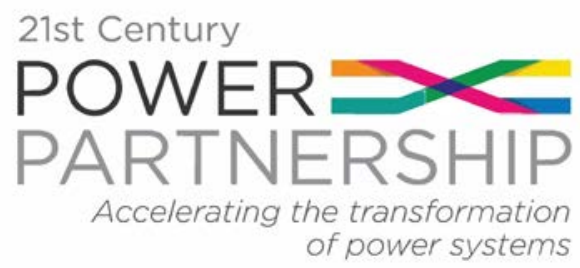

NREL is a national laboratory of the U.S. Department of Energy Office of Energy Efficiency \& Renewable Energy Operated by the Alliance for Sustainable Energy, LLC

This report is available at no cost from the National Renewable Energy Laboratory (NREL) at www.nrel.gov/publications.

Technical Report

NREL/TP-6A20-67462

March 2017

Contract No. DE-AC36-08GO28308 


\section{Transmission Challenges and Best Practices for Cost- Effective Renewable Energy Delivery across State and Provincial Boundaries}

David Hurlbut, Ella Zhou, Lori Bird, and Qin Wang National Renewable Energy Laboratory

Prepared under Task No. ACTC.1320

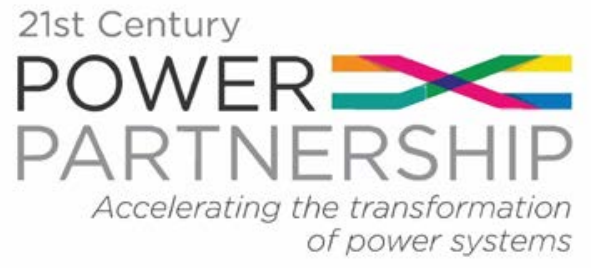

National Renewable Energy Laboratory 15013 Denver West Parkway Golden, CO 80401

303-275-3000 • www.nrel.gov
NREL is a national laboratory of the U.S. Department of Energy Office of Energy Efficiency \& Renewable Energy Operated by the Alliance for Sustainable Energy, LLC

This report is available at no cost from the National Renewable Energy Laboratory (NREL) at www.nrel.gov/publications.

\section{Technical Report}

NREL/TP-6A20-67462

March 2017

Contract No. DE-AC36-08GO28308 


\title{
NOTICE
}

This report was prepared as an account of work sponsored by an agency of the United States government. Neither the United States government nor any agency thereof, nor any of their employees, makes any warranty, express or implied, or assumes any legal liability or responsibility for the accuracy, completeness, or usefulness of any information, apparatus, product, or process disclosed, or represents that its use would not infringe privately owned rights. Reference herein to any specific commercial product, process, or service by trade name, trademark, manufacturer, or otherwise does not necessarily constitute or imply its endorsement, recommendation, or favoring by the United States government or any agency thereof. The views and opinions of authors expressed herein do not necessarily state or reflect those of the United States government or any agency thereof.

This report is available at no cost from the National Renewable Energy Laboratory (NREL) at www.nrel.gov/publications.

Available electronically at SciTech Connect http:/www.osti.gov/scitech

Available for a processing fee to U.S. Department of Energy and its contractors, in paper, from:

\author{
U.S. Department of Energy \\ Office of Scientific and Technical Information \\ P.O. Box 62 \\ Oak Ridge, TN 37831-0062 \\ OSTI http://www.osti.gov \\ Phone: 865.576.8401 \\ Fax: 865.576.5728 \\ Email: reports@osti.gov
}

Available for sale to the public, in paper, from:

\author{
U.S. Department of Commerce \\ National Technical Information Service \\ 5301 Shawnee Road \\ Alexandria, VA 22312 \\ NTIS http://www.ntis.gov \\ Phone: 800.553 .6847 or 703.605 .6000 \\ Fax: 703.605.6900 \\ Email: orders@ntis.gov
}




\section{Acknowledgments}

This report is a part of the "Boosting Renewable Energy as Part of China's Energy Revolution" program, a five-year multilateral effort supported by the Children's Investment Fund Foundation in the United Kingdom. The Program includes a series of technical collaboration between National Renewable Energy Laboratory (NREL), $21{ }^{\text {st }}$ Century Power Partnership, China National Renewable Energy Center (CNREC), Danish Energy Agency, Deutsche Gesellschaft für Internationale Zusammenarbeit (GIZ), and other key research institutes and energy experts in China, United States, Denmark, and Germany.

The authors would like to thank Weiming Xiong from the Energy Research Institute of (China) National Development and Reform Committee, Frederick Weston from the Regulatory Assistance Project, and Cheng Luo from the Midcontinent Independent System Operator for their inputs and review of the report. For their review and comments, we would like to thank the following NREL colleagues: Douglas Arent, John, Barnett, Michael Milligan, Paul Schwabe, and Jeffrey Logan. 


\section{Acronyms}

$\begin{array}{ll}\text { AC } & \text { alternating current } \\ \text { BA } & \text { balancing authority } \\ \text { BPA } & \text { Bonneville Power Administration } \\ \text { CSG } & \text { China Southern Power Grid Company } \\ \text { CSP } & \text { concentrated solar power } \\ \text { DA } & \text { day-ahead } \\ \text { DIR } & \text { dispatchable intermittent resources } \\ \text { FERC } & \text { Federal Energy Regulatory Commission } \\ \text { FTP } & \text { financial transmission right } \\ \text { GW } & \text { gigawatts } \\ \text { HVDC } & \text { high-voltage direct current } \\ \text { LMP } & \text { locational marginal price } \\ \text { MISO } & \text { Midcontinent Independent System Operator } \\ \text { MW } & \text { megawatt } \\ \text { NDRC } & \text { National Development and Reform Commission of China } \\ \text { OASIS } & \text { open-access, same-time information system } \\ \text { OATT } & \text { open access transmission tariff } \\ \text { POD } & \text { point-of-delivery } \\ \text { POR } & \text { point-of-receipt } \\ \text { PSS } & \text { physical scheduling system } \\ \text { PTP } & \text { point-to-point } \\ \text { PV } & \text { photovoltaic } \\ \text { RE } & \text { renewable energy } \\ \text { REC } & \text { Renewable Energy Certificate } \\ \text { RPS } & \text { Renewable Portfolio Standards } \\ \text { RTO } & \text { regional transmission organization } \\ \text { SCED } & \text { security-constrained economic dispatch } \\ \text { SCUC } & \text { security-constrained unit commitment } \\ \text { SGCC } & \text { State Grid Corporation of China } \\ \text { SOCO } & \text { Southern Company Services } \\ \text { TUC } & \text { transmission usage charge } \\ \text { TWh } & \text { terawatt hours } \\ \text { UHV } & \text { ultra-high voltage } \\ \text { VAT } & \text { value-added tax } \\ & \end{array}$




\section{Table of Contents}

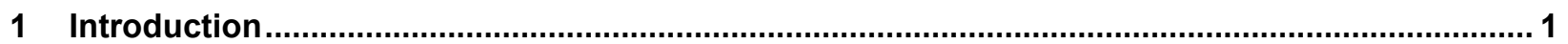

2 Challenges in Cross-Provincial Consumption of Renewable Energy in China ........................... 1

2.1 Renewable Development and Transmission Network in China........................................... 1

2.2 Inter-Regional/Provincial Transmission Issues in China ....................................................... 4

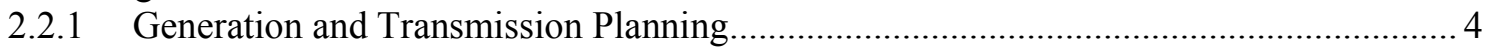

2.2.2 Inter-Regional/Provincial Power Exchange Scheduling and Trading ..............................5

2.2.3 Inter-Regional and Inter-Provincial Power Exchange Pricing ....................................... 6

2.2.4 Impact of Tax Policy on Inter-Provincial Trading ................................................... 7

2.3 Experiments in Inter-Regional/Provincial Electricity Trading in China .................................... 8

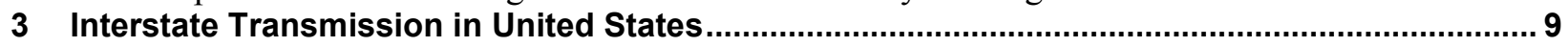

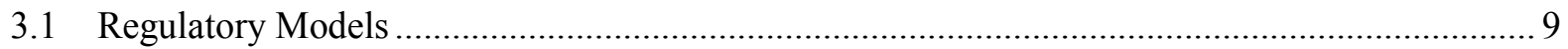

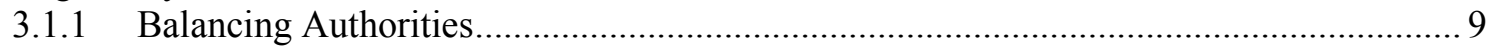

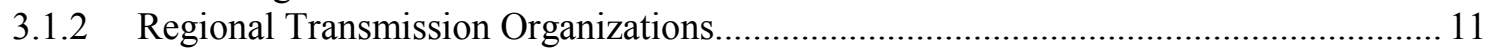

3.2 Drivers for Interstate Transmission in the United States that are Related to Renewables .......... 12

3.3 Models for Planning and Using Cross-State Transmission ................................................... 14

3.3.1 Wheeling across Existing Transmission between BAs ............................................... 14

3.3.2 Direct Purchase within a Multi-State RTO ............................................................... 14

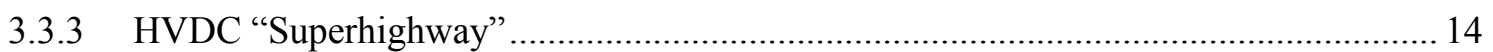

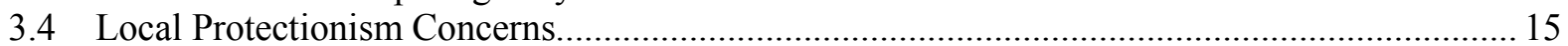

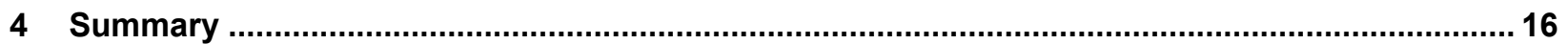

Appendix: RTO Case Study of Midcontinent Independent System Operator.................................... 18

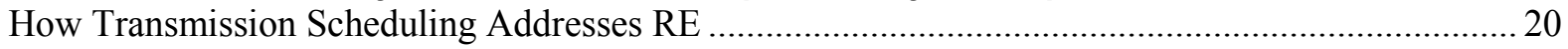

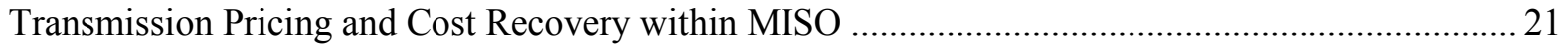

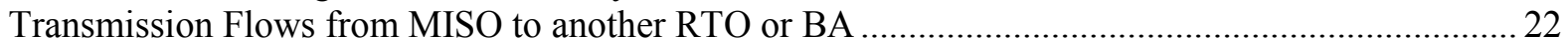

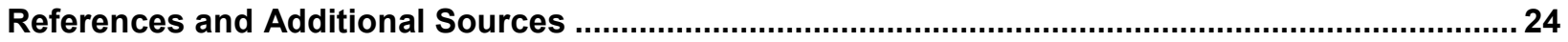




\section{List of Figures}

Figure 1. Map of regional grids on mainland China ............................................................................ 3

Figure 2. MISO (unshaded area) and U.S. wind development .......................................................... 18

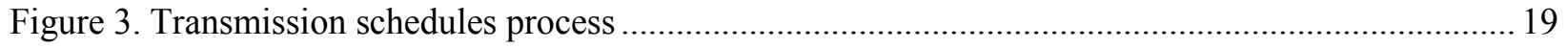

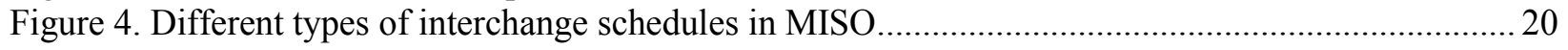

\section{List of Tables}

Table 1. Construction Status of Estimated Needed Transmission Additions for the Wind Energy Bases

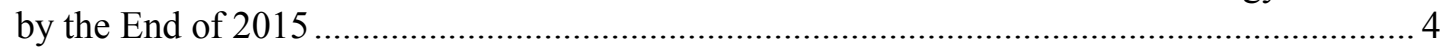

Table 2. Inter-Regional/Inter-Provincial Scheduling and Trading Information for 2010 ......................... 5

Table 3. Average On-Grid Tariff for Various Generation Technologies and Residential Electricity Prices in Selected Provinces (Renminbi per Kilowatt-Hour) .................................................... 7

Table 4. Real-Time Market Resource Comparison....................................................................... 21

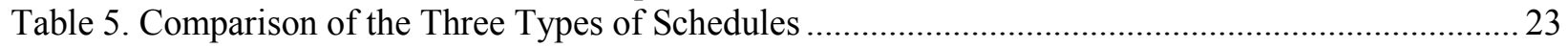




\section{Introduction}

A strategically planned transmission network is an important source of flexibility for the integration of large-scale renewable energy (RE). Such a network can offer access to a broad geographic diversity of resources, which can reduce flexibility needs and facilitate sharing between neighboring balancing areas (Cochran et al. 2014; Milligan et al. 2015). This report builds on two previous NREL technical reports-Advancing System Flexibility for High Penetration Renewable Integration (Milligan et al. 2015) and 'Renewables-Friendly' Grid Development Strategies (Hurlbut et al. 2015) — which discuss various flexibility options and provide an overview of U.S. market models and grid planning. This report focuses on addressing issues with cross-regional/provincial transmission in China with the aim of integrating renewable resources that are concentrated in remote areas and require inter-regional/provincial power exchange.

Many previous studies have focused on long-distance transmission as a challenge for renewable integration in China (Cheung 2011; IRENA 2014; Ni and Yang 2012; Kahrl and Wang 2015). Three aspects of China's inter-provincial transmission process are important to RE integration: planning, power exchange scheduling, and pricing. The experience of the United States in transmission planning is given in the 'Renewables-Friendly' Grid Development Strategies report; in this report, we examine U.S. experience in transmission scheduling, pricing, access, and allocation and we look closely at cases in both regional transmission organization (RTO) regions and non-RTO regions, and implications for consideration in China.

\section{Challenges in Cross-Provincial Consumption of Renewable Energy in China}

\subsection{Renewable Development and Transmission Network in China}

Over the past ten years, China has seen tremendous growth in RE development accompanied by high levels of curtailment. The amount of wind curtailment in China hit a record high of 33.9 terawatt hours (TWh) in 2015, representing an average wind curtailment rate of $15 \%$, and reached as high as 39\% in Gansu Province (NEA 2016c). The average solar curtailment was $12.6 \%$ in 2015 and $30.7 \%$ in Gansu (CPIA 2016).

One of the major challenges for China's RE integration, and an impetus for cross-provincial transmission, is that the RE resources are located far from the load centers. This heightens the need for inter-regional and inter-provincial transmission, as resource-rich areas are not able to consume all of what they generate locally. By the end of 2015, the cumulative installed capacity of wind power reached 145.36 gigawatts (GW) in China, $51.7 \%$ of which is located in only five provinces/autonomous regions (Inner Mongolia, Xinjiang, Gansu, Hebei, and Shandong) in the northern part of China (CWEA 2016). Installed capacity of solar reached $43.18 \mathrm{GW}$ in 2015; four Northern provinces (Gansu, Xinjiang, Qinghai, and Inner Mongolia) account for 51.6\% (NEA 2016a). China's load centers, however, are located along the coast. The resource and load mismatch is further exacerbated by the economic slowdown: the electricity consumption in the State Grid Corporation of China (SGCC) territory only grew by $0.1 \%$ in 2015 , and the growth rates of electricity consumption in the Northeast, Northwest, and North China regions are lagging behind that of the eastern regions (SGCC 2016a). 
China has significant grid infrastructure, but the current institutional setup is not fully conducive to cross-provincial consumption of RE (see Section 2.2). Mainland China has seven regional grids (six synchronous grids): Northeast Grid, Northwest Grid, North China Grid, Central China Grid, East China Grid, South China Grid, and Tibet Grid. Among them, North China Grid and Central China Grid are synchronized through the Jindong-Jingmeng 1,000kV HVAC project. Balancing is primarily done at the provincial level rather than at the regional level. Over the years, China has been building a significant amount of inter-regional and inter-provincial transmission. By the end of 2013, 15 inter-regional transmission lines, totaling 12,739 km, were in operation in China, all owned by SGCC; 219 inter-provincial lines, $43,255 \mathrm{~km}$ in total, were in operation, 153 of which are owned by SGCC and the rest by China Southern Power Grid Company (CSG) (NEA 2015a). Some of the inter-regional and inter-provincial transmission projects were primarily built for RE integration purposes, including the Northeast Grid-North China Grid back-to-back high-voltage, direct current (HVDC) expansion project, and the $800 \mathrm{kV}$ Hami-Zhengzhou ultra-high voltage direct current (UHV DC) project (SGCC 2016b). The necessity for inter-regional and inter-provincial power exchange has been an integral feature of the Chinese power system, albeit not primarily for wind and solar integration. In 2015, interregional/provincial power exchange reached $884.2 \mathrm{TWh}, 15.9 \%$ of total electricity consumption nationally (NEA 2016b). With the construction of more UHV transmission, inter-regional and inter-provincial power flows could play an even greater role in the integration of renewable energy in this resource-load-unbalanced country. Figure 1 shows an illustration of major current and planned transmission lines in the seven regional grids, along with approximate provincial load sizes and RE source availability. 
South China Grid

East China Grid

North China Grid

Central China Grid

Northeast Grid

Northwest Grid

Tibet Grid

Energy Consumption

Solar Resource Rich Areas: Xinjiang Tibet

Inner Mongolia

Qinghai

$\approx$ Wind Resource Rich Areas: Inner Mongolia Xinjiang Gansu
Heilongjian Jilin

- - - UHV AC lines under construction

_ UHV AC lines

- - - UHV DC lines under construction

UHV DC

_ High Voltage DC lines

Names and boundary representation are not necessarily authoritative.

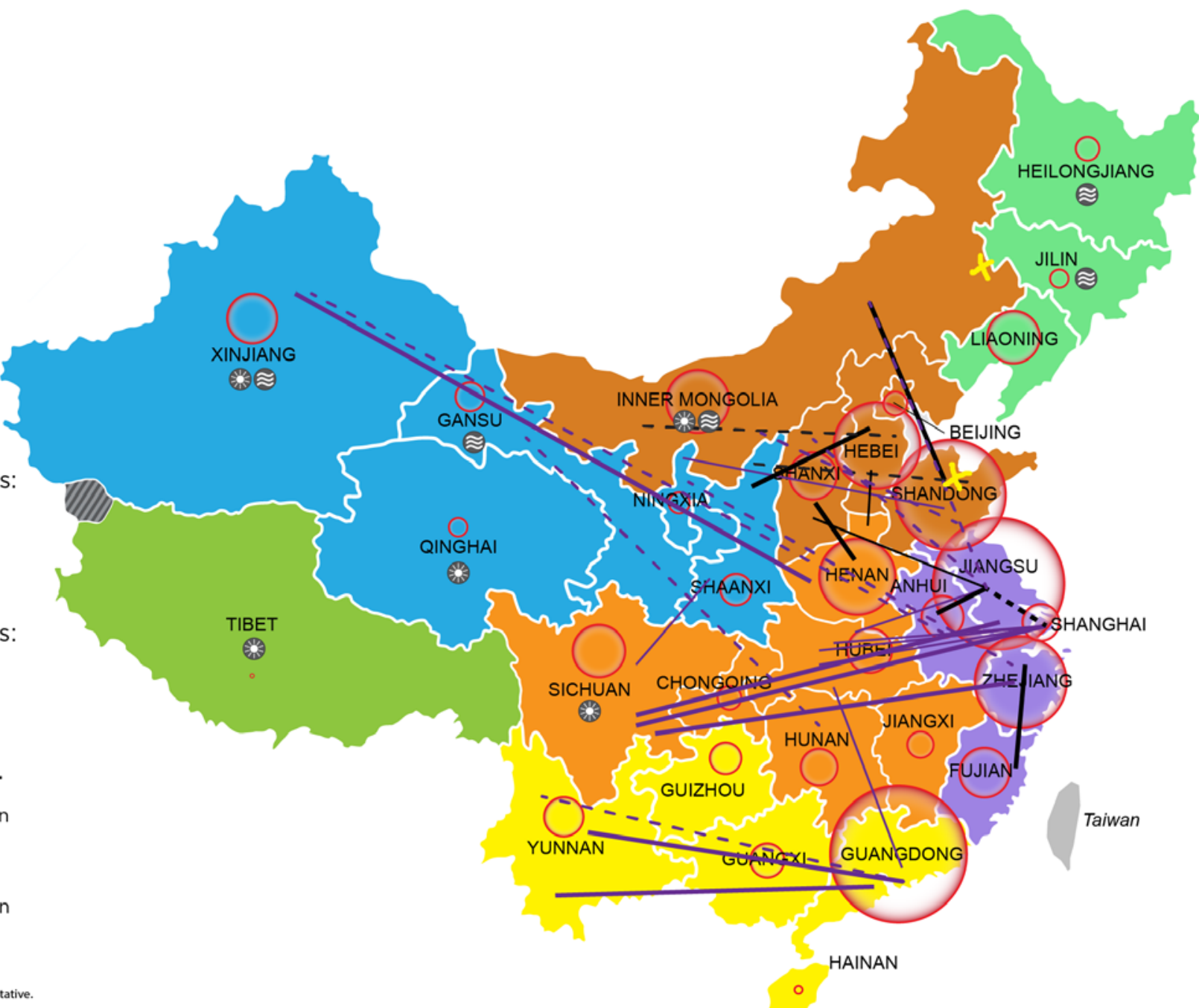

Figure 1. Map of regional grids on mainland China

Sources: NEA, SGCC, CSG 


\subsection{Inter-Regional/Provincial Transmission Issues in China}

A series of issues related to inter-regional and inter-provincial transmission has hindered the integration of renewables. These include uncoordinated planning of generation and transmission, administrative planning of the network power exchange, and pricing and trading mechanisms.

\subsubsection{Generation and Transmission Planning}

The 2015 power sector reform document (often referred to as "Paper No. 9") calls for strengthening coordinated planning of the power sector (NDRC 2015). Currently, RE generation planning is not coordinated with transmission planning. During the $12^{\text {th }}$ Five-Year Plan (20102015) period, China released specific planning documents for wind and solar generation but did not provide any guideline for grid planning to meet the transmission needs of these new generation bases (Wang 2016). Analysts found that the approval and construction of a typical wind farm in China take slightly more than 20 months, but the corresponding grid would take more than 40 months to be planned, approved, and constructed, lagging far behind China's RE deployment (Wang 2016). Table 1 shows the planned capacity of seven of China's large wind energy bases and the needed additional transmission capacity as estimated by the State Grid Energy Research Institute, along with the construction status of those transmission lines. Note that not all estimated needed transmission additions result in a concrete plan of construction. The table helps to illustrate that the planning and construction of the large-scale wind energy bases in China are well ahead of those for transmission.

Table 1. Construction Status of Estimated Needed Transmission Additions for Wind Energy Bases by the End of 2015

\begin{tabular}{|l|l|l|l|l|l|l|l|}
\hline & Hami & Jiuquan & $\begin{array}{l}\text { West } \\
\text { Inner } \\
\text { Mongolia }\end{array}$ & $\begin{array}{l}\text { East } \\
\text { Inner } \\
\text { Mongolia }\end{array}$ & Jilin & Heilongjiang & Zhangbei \\
\hline $\begin{array}{l}\text { Planned wind } \\
\text { capacity (GW) in } \\
2015^{a}\end{array}$ & 9 & 13 & 13 & 7 & 8 & 6 & 10 \\
\hline $\begin{array}{l}\text { Planned wind } \\
\text { capacity (GW) in } \\
2020\end{array}$ & 17 & 15 & 38.3 & 13 & 15 & 10 & 16 \\
\hline $\begin{array}{l}\text { Needed additional } \\
\text { transmission } \\
\text { capacity (GW) }\end{array}$ & 10 & 11 & 13 & 8 & 6 & 6 & 11 \\
\hline Transmission Lines & Completed & Under Construction & No Transmission Construction Plan \\
\hline
\end{tabular}

${ }^{a}$ Installed capacity is not available for all the wind bases at the time of writing, but it is safe to assume that they have met their planned installation targets by 2015

Source: Liu 2016, RAP 2016

On the other hand, some recently built inter-provincial transmission lines have low utilization factors due to predominantly generation and transmission planning issues. The highest capacity utilization to date at the cross-section of the four-circuit $750 \mathrm{kV}$ transmission from Xinjiang to the Northwest Grid for instance, was $2 \mathrm{GW}$ in 2014, less than half of its rated capacity. (NEA 2016e) This is primarily because of the slowdown in Qinghai Province's load growth and its own local renewable energy development, as well as the delay in generation built in Xinjiang Province. 
The Electric Power Planning Management Measures, released in June 2016, is an effort to coordinate the planning efforts at the central and provincial level across different NEA departments and entities. According to the Measures, NEA is responsible for power sector planning at the national (and regional) level, which should include large hydro, nuclear, wind, solar (photovoltaic [PV] and concentrated solar power [CSP]), and coal generation planning, as well as inter-regional/provincial transmission projects, intra-provincial transmission projects above $500 \mathrm{kV}$, and the scale of provincial self-consumption coal and gas generation. This planning would be done by power-sector-planning research institutes and implemented by power companies (NEA 2016d).

\subsubsection{Inter-Regional/Provincial Power Exchange Scheduling and Trading}

One of the main issues with the inter-regional and inter-provincial power exchange is that the vast majority of the electricity transferred between the provinces is planned administratively (both the amount and the price) on an annual basis. Table 2 shows a breakdown of the different types of inter-regional and inter-provincial power exchanges in 2010.

Table 2. Inter-Regional/Inter-Provincial Scheduling and Trading Information for 2010

\begin{tabular}{|c|c|c|c|}
\hline Type & Examples & $\begin{array}{l}\text { Electricity } \\
\text { Transferred } \\
\text { (TWh) }\end{array}$ & $\begin{array}{l}\text { Price and Amount } \\
\text { Formation }\end{array}$ \\
\hline $\begin{array}{l}\text { Central government } \\
\text { ordered or approved } \\
\text { interchange }\end{array}$ & $\begin{array}{l}\text { Transfer of generation from the } \\
\text { Three Gorges Dam, Gezhou } \\
\text { Dam, and Lijiaxia Dam; inter- } \\
\text { regional and some inter-provincial } \\
\text { transmission in the Northeast } \\
\text { Region; transfer from Sichuan } \\
\text { and Anhui Province to the east }\end{array}$ & 352.7 & $\begin{array}{l}\text { Set by the central } \\
\text { government }\end{array}$ \\
\hline $\begin{array}{l}\text { Provincial government } \\
\text { led transfer }\end{array}$ & $\begin{array}{l}\text { Transfer from the west to the east } \\
\text { in the Southern China Grid }\end{array}$ & 95.9 & $\begin{array}{l}\text { Set by provincial } \\
\text { governments }\end{array}$ \\
\hline $\begin{array}{l}\text { Grid company } \\
\text { scheduled transfer }\end{array}$ & $\begin{array}{l}\text { UHV transfer, Northern China } \\
\text { Grid to Central China Grid } \\
\text { transfer, Anhui export (except to } \\
\text { the east) }\end{array}$ & 19.2 & Set by grid companies \\
\hline Partial market trading & $\begin{array}{l}\text { Transfer in Northwest, Central } \\
\text { China, Eastern China, and } \\
\text { Northern China Grids except the } \\
\text { capacity set through previous } \\
\text { types }\end{array}$ & 107.3 & $\begin{array}{l}\text { Scheduled by SGCC or } \\
\text { negotiated between the } \\
\text { regional/provincial grids. } \\
\text { The amount is } \\
\text { determined through } \\
\text { bidding by the } \\
\text { generators or through } \\
\text { procurement, etc. }\end{array}$ \\
\hline Market trading & $\begin{array}{l}\text { Eastern China monthly bidding; } \\
\text { Central China hydro emergency } \\
\text { trading; Yunan hydro to } \\
\text { Guangdong Province that } \\
\text { exceeds the previously planned } \\
\text { amount }\end{array}$ & 5.1 & $\begin{array}{l}\text { Negotiated between the } \\
\text { grid and the generation } \\
\text { company }\end{array}$ \\
\hline
\end{tabular}

Source: SERC 2011 
More recent numbers are not available, but NEA's 2016 report on national electricity trading stated that planned arrangements and provincial government negotiation are still the primary ways in which the inter-regional/inter-provincial power exchange amount and prices are decided (NEA 2016b). Some provincial governments extensively intervene in the inter-regional and inter-provincial trading. For example, the Energy Administration of Jiangxi Province set a quota for the Jiangxi Provincial Grid to import no more than 10 TWh of electricity, including the scheduled transfer from the Three Gorges Dam and Gezhou Dam set by the central government, and requires government approval whenever import needs arise. It even ordered the provincial grid to cancel the trade of 733 gigawatt-hours of electricity after the trading had already been completed on the market (NEA 2016b). In southern China, provincial government maneuvering makes it difficult to reach an annual contract; by June 30, 2015, the governments still had not signed a contract for 2015 inter-provincial trading, and a great portion of the inter-provincial power exchange went through without any contractual basis (NEA 2016b). Several reasons motivate such local government behavior, one of which is discussed in Section 2.2.4; others such as local government official performance evaluation metrics are outside the scope of this technical report.

The administrative plans are relatively stable from year to year with few short-term mechanisms for adjustment. From January to April of 2013, for example, Central China Grid had excess generation overall, but the grid still imported 6.34 TWh from Northern China Grid and 2.25 TWh from Northwest Grid as scheduled in the annual plan (NEA 2014). Short-term interprovincial trading is very limited, often used for emergency purposes only, and short-term interregional trading is almost non-existent (Central China Electricity Regulatory Bureau 2014; Eastern China Grid Company 2016). As a result, the inefficiencies in the annual administrative scheduling plan often cannot be adjusted in a timely manner.

\subsubsection{Inter-Regional and Inter-Provincial Power Exchange Pricing}

The third main issue for inter-provincial power exchange is pricing. The government sets the ongrid tariff and sales price for electricity generated from various sources in each province. And, the grid companies use the spread between the electricity sales price and the on-grid tariff to cover their transmission and distribution costs. The coal on-grid tariff is also known as the "benchmark" price; RE receives a feed-in tariff on top of the benchmark price, which makes their on-grid tariff higher than the price of electricity from conventional sources. For example, Table 3 shows the 2015 average on-grid tariff prices for different sources of generation in selected provinces.

As seen from Table 3, even though provinces with abundant RE resources such as Xinjiang and Gansu have lower electricity sales prices than Henan, Hunan, and Shandong, the tariffs for RE generation there are still much higher than the coal on-grid tariffs in the latter provinces. As a result, when the inter-provincial trading is conducted under the existing framework of administratively determined tariff regime, $\mathrm{RE}$ generation is not competitive against coal for cross-provincial consumption. 
Table 3. Average On-Grid Tariff for Various Generation Technologies and Residential Electricity Prices in Selected Provinces (Renminbi per Megawatt-Hour)

\begin{tabular}{lrrrrrc}
\hline Province & Coal & Gas & Hydro & PV & Wind & $\begin{array}{c}\text { Average } \\
\text { Electricity } \\
\text { Sales Price }\end{array}$ \\
\hline Xinjiang & 247.3 & NA & 248.8 & 974.2 & 559.8 & 436.81 \\
Gansu & 295.9 & NA & 239.5 & 1003.0 & 529.8 & 453.00 \\
Henan & 421.3 & 786.53 & 340.3 & NA & 609.9 & 606.83 \\
Hunan & 473.7 & NA & 361.3 & NA & 599.9 & 675.06 \\
Shandong & 421.1 & NA & NA & 1000.0 & 674.3 & 697.75 \\
\hline
\end{tabular}

Source: NEA $2016 f$

In addition, the current inter-provincial and inter-regional power exchange prices are set through central administrative planning and provincial government negotiation and do not realistically reflect supply and demand. In fact, the administratively set price is usually higher than what the market price would be, as indicated in the pilot trading discussed in Section 2.3. Even for the "market trading" portion, during which prices are negotiated by the grid and the generation companies, the prices are not always fair due to regulation inadequacy and information asymmetry. For instance, Chinese regulation requires the grid operator to provide generation companies with network typology, load, and main transmission corridor information (SERC 2005); in practice, such information is only disclosed to the regulators. Some SGCC dispatch and trading agencies did not disclose transmission network typology to the generation companies, and some did not disclose line congestion or day-ahead (DA) scheduling information as required (NEA 2016b). ${ }^{1}$ Some research suggests that the on-grid tariff can be relatively low while the transmission price is relatively high in China. (CSER 2012)

In addition to the government-set portion of the inter-regional/provincial power exchange, some provincial governments negotiate the partial market or market trading prices as well. In 2015, Guangdong Province and Yunnan Province agreed to offer the excess electricity in Yunnan (beyond the government-set plan) for public trading, but the generators did not participate in the price negotiations; instead, the provincial governments settled the price for them. CSG provided an estimate of the amount of potential power exchange based on system conditions (NEA 2016b).

\subsubsection{Impact of Tax Policy on Inter-Provincial Trading}

The benefits of the transmission network for large-scale RE integration are well understood in China. Yet cross-regional/provincial consumption of RE is not primarily constrained by the physics of the transmission system, but rather by the political and economic interests of the importing and exporting provinces.

\footnotetext{
${ }^{1}$ Because the "market trading" portion is very small in terms of total electricity generation, the regulatory agency and the grid companies are not concerned with generation companies distorting the market with their market power given the disclosed information. This may change with the power market reform.
} 
After the 1994 tax reform in China, the local government tax sources shrunk significantly. Sales tax and customs duty go to the central government. Corporate income tax goes to either the central or the local government, depending on the corporation's affiliation. In other words, income tax from national-level, state-owned enterprises (such as SGCC) is paid to the central government, and income tax from provincial-level state-owned enterprises (such as Zhejiang Provincial Energy Group, which owns more than half of the generation assets in Zhejiang) is paid to the provincial government. Value-added tax (VAT) is split 3:1 between the central and local governments. Most resource tax (such as for coal) goes to local governments with the exception of oceanic resources and oil taxes, which are paid to the central government (MOF 2014). As a result, the provincial governments have a strong incentive to keep the local generation companies and coal companies profitable in order to retain local government revenue and local employment, instead of having a slightly lower electricity price that may increase the government revenue from VAT. With the current economic slow-down, provinces are increasingly reluctant to import power from out of state.

\subsection{Experiments in Inter-Regional/Provincial Electricity Trading in China}

To break the bottlenecks described above, the National Development and Reform Commission (NDRC) released a Notice on Improving Inter-Regional/Provincial Electricity Trading PriceFormation Mechanism and Related Issues to instruct power trading participants to negotiate prices themselves or utilize a market; it further directs that new inter-regional/provincial traded generation projects would be selected through competitive bidding (NDRC 2015).

Another potential channel through which to liberalize the inter-regional and inter-provincial power exchange is direct power purchasing or offering cross-provincial retail options. In the past 10 years, most of the direct power purchasing has been limited to intra-provincial, but recently it has been raised as a potential way of addressing the inter-regional and inter-provincial power exchange issue (Bai et al. 2016). In 2016, NDRC issued an order to open up regional transmission scheduling to direct power purchasing for the first time, including10-12 TWh (35.7 to $42.9 \%$ ) of the scheduled transmission on the Yindong HVDC transmission line (NDRC 2016). 824 generation companies in four Northwest provinces and 30 end-users in Shandong Province participated in the trading, resulting in a 10\% reduction of electricity prices for the end consumers in Shandong (Caixin Energy 2016; South China Morning Post 2016).

Nevertheless, the concluded deals were all from coal generators, whose offering price was relatively lower than the price offered by renewable generators, reflecting the respective government-set on-grid tariffs mentioned in Section 2.2.3. Therefore, a fundamental change in the electricity pricing mechanism is needed for renewables to compete on a level playing field with coal. 


\section{Interstate Transmission in United States}

Transmission planning, scheduling, and pricing follow two established models in the United States. In this section, we introduce the two models and then describe in detail the more complex of the two. The discussion then examines how interstate transmission happens against these two institutional frameworks.

\subsection{Regulatory Models}

The United States has two institutional models for generator access to transmission: regional transmission organizations (RTOs) and non-RTO balancing authorities (BAs). Non-RTO BAs are the traditional mode of operation and are comparable to China's provincial grids. RTOs are more recent, having evolved over the past two decades in regions with relatively high populations and load density. RTOs are geographically comparable to China's regional grid systems but exert a larger degree of operational control.

\subsubsection{Balancing Authorities}

A BA area is the geographic unit within which total metered generation is adjusted to match total metered demand. A BA can be a single large transmission utility or it can be a joint operating agreement among a number of transmission utilities operating in the same BA. Usually a BA is contained within one state as a consequence of regulatory history, and one state may contain more than one BA. Some large BAs in the United States cross state borders, often as the result of mergers and acquisitions that combined small utilities into large ones.

The flow of electricity from one BA to another is tracked separately and included in the balancing calculation. The BA manages spinning reserves on its system so that

$$
\text { generation }_{t}+\text { imports }_{t}=\operatorname{load}_{t}+\text { exports }_{t}
$$

for each operating interval $t$ (NERC 2016). Most imports and exports between BAs are either commercial wheeling of electricity from a generator in one BA to load in another or short-term direct transactions by the BAs for reliability. The BA is also responsible for supporting system frequency in real time.

The significant characteristic of the BA model is that transmission owners retain control of their own systems separately from one another, subject to federal laws and regulations. The terms of providing transmission service are contained in each owner's open access transmission tariff (OATT), which must be reviewed and approved by the Federal Energy Regulatory Commission (FERC). States may not modify transmission rates approved by FERC (TETCO v. FERC 1996).

The OATT addresses three types of transmission customers (FERC 2007):

- Native Load Customers: A utility may own transmission and at the same time have a legal obligation to serve end-use customers. Native load customers are those the utility's transmission network must serve because of law, state franchise, regulatory requirement, or contract.

- Network Service Customers: Load served by a network service customer is functionally similar to the utility's native load, except that there is no franchise or similar legal 
obligation between the customer and the transmission utility. A network service customer can be a municipally owned utility serving its own load, or it can be a large industrial firm with its own generators.

- Point-to-Point (PTP) Service Customers: PTP customers purchase service to move electricity from a specific point of interconnection on the transmission utility's system to a specific point of delivery, often to a point of interchange with an adjacent transmission network. PTP customers do not serve native load or network load.

Native load customers and network customers must designate generators as their network resources. Generally, a designated network resource must be available for firm service to network load at all times and may not be obligated to a non-network third party.

Federal regulations require that the transmission utility disclose the methodology it uses to calculate the amount of transmission capability available for PTP service. This normally involves combining an estimate of transmission system needs by native load and network customers with obligations under other long-term contracts, and then estimating the remaining capacity that can be served without curtailment. Both the methodology and the resulting availability must be posted publicly on the transmission utility's open-access, same-time information system (OASIS). PTP service is available on a first-come, first-served basis.

Transmission utilities may sell both firm and non-firm PTP service. Firm PTP service has equal reservation priority with native load customers and network customers. Non-firm PTP service may be reduced, if needed, to serve other transmission customers.

Because each transmission utility has its own tariff, wheeling power from one BA to another involves multiple sets of PTP charges - one for each BA along the path of the transaction. This practice of layering one level of PTP charges onto another is often called "pancaking," and can result in significant transmission costs for moving electricity long distances.

If curtailment is necessary to maintain grid reliability, the transmission utility must treat network and firm PTP customers in the same way it treats its own resources. The BA must curtail and redispatch resources in a manner that relieves transmission congestion at the least cost, without discriminating in favor of its own resources. If curtailment and redispatch are not enough to maintain reliability, load shedding must also be done on a nondiscriminatory basis.

Apart from limits on non-firm PTP service, the only priority for transmission access is for the continuation of firm service already under contract to a customer. This applies to any type of transmission customer. Although native load customers do not have priority over network or firm PTP customers, the transmission utility may have a statutory or regulatory obligation to upgrade its transmission system if needed to serve native load customers. Moreover, because the transmission utility is required to treat network and PTP customers the same as it treats itself, the need for transmission expansion is driven equally by the need to serve native load, network load, and firm PTP demand. 


\subsubsection{Regional Transmission Organizations}

RTOs in the United States combine several BAs into a single control area. A transmissionowning utility inside an RTO does not control the flow of power over its system, as it does in a BA. The RTO operates under a consolidated OATT that governs the use of every transmission line owned by all utilities that are in the RTO. All the transmission systems are operated as a single transmission system (PJM 2010).

The regional network operated by the RTO is indifferent to state boundaries that fall within its footprint. ${ }^{2}$ All generators have equal access to the transmission network at their points of interconnection regardless of which state they are in, provided they meet the RTO's requirements for interconnection. These requirements pertain to telemetry standards, having an agent to submit economic offers on behalf of the generator, and other technical requirements that apply equally to all generators.

The RTO conducts security-constrained economic dispatch (SCED) to determine which generators are allowed to send power over the transmission system and which are not. SCED optimizes generator dispatch across all the states covered by the RTO based on generator costs (bid prices) and transmission limits (ERCOT 2016; PJM 2010). Therefore, a load center in one state could be served by generation in other states if such interstate dispatch results in a lower total cost of generation.

All load in an RTO is network load, and all generation connecting to the RTO system is network generation. Therefore, there is no PTP transmission service from one point to another (even if the points are in different states), and no differentiation between firm and non-firm transmission service. Generator dispatch is determined by the offer prices submitted by generators and suppliers of demand response throughout the RTO, optimized in the SCED. The lowest-price offers are dispatched, subject to transmission constraints, generator ramping constraints, and reliability requirements. Wind and solar resources, which have zero or near-zero marginal generation costs, typically bid zero or near-zero offer prices. SCED reduces a generator's dispatch level economically based on the price at which the generator has offered its energy into the market. This means that there is very little physical curtailment of wind power or any other resource, except for unusual reliability events.

Generators that are dispatched receive payment at prices determined by the SCED. These are known as locational marginal prices (LMPs) and are specific to each point at which electricity is generated or consumed. An LMP represents the cost to the entire system of providing an additional megawatt-hour of energy at the given location. If there is transmission congestion on the system, LMPs will take on different values at different locations to account for the cost of that congestion (i.e., system redispatch that reflects the cost of meeting demand with resources that would not be operated if there were no congestion).

\footnotetext{
${ }^{2}$ The Electric Reliability Council of Texas and the New York Independent System Operator are RTOs that combined BAs that are all located entirely within their respective states.
} 
Because of their use of SCED, RTOs have no physical transmission rights and no guarantee of dispatch from one point on the system to another. In these cases, RTOs use LMPs to compute financial transmission rights (FTRs), also called congestion revenue rights (PJM 2010; ERCOT 2016). These instruments replace physical PTP transmission service with the ability to hedge against congestion between two points on the grid. Thus, if a generator wants to move power to load at a distant point on the system but anticipates transmission congestion between the two points, it can secure FTRs that will provide the generator with supplemental revenue when congestion occurs. This gives the generator more flexibility to reduce the price it offers into the market, thus reducing the likelihood that it would be curtailed in SCED. FTRs are calculated through power flow modeling conducted by the RTO to identify likely congestion paths. Most FTRs are assigned by month and auctioned monthly, although some may be reserved for 6- or 12-month periods.

The RTO considers LMP differences in determining whether transmission upgrades are reasonable. If the long-term cost of congestion as indicated by the affected LMPs is higher than the cost of the transmission upgrade, the RTO often will authorize the upgrade.

RTOs in the United States that are adjacent to one another rely on joint operating agreements to manage the flow of power from one RTO to another. For the purposes of SCED, a transmission interface with another RTO is represented as another node on the edge of the system. The flow of power is managed in accordance with the joint operating agreement with respect to reliability, but the prices at which the transactions are settled are calculated in the SCED.

The point of interchange between two RTOs is represented as a node in each RTO's separate SCED. For example, moving wind generation from one RTO to load in another RTO would involve two simultaneous scheduling efforts. In the RTO where the wind generator is located, the node would be scheduled as load corresponding to the amount of power to be sent. In the receiving RTO's SCED, energy would be scheduled as generation injected at the interchange node. The two SCED runs would determine the price at which the power would flow across the interchange. Managing reliability issues associated with the exchange would be addressed by the RTOs in accordance with their joint operating agreement.

Exchanges between RTOs and non-RTO BAs may be managed using trading hubs. A hub represents a high-volume transmission interchange, usually a junction of several high-voltage transmission paths converging on a major generating station. A hub outside the RTO's service area that has a transmission path into the RTO may be assigned a virtual node.

\subsection{Drivers for Interstate Transmission in the United States that are Related to Renewables}

In the United States, transfers of renewable energy across state lines are common. Some of the first large high-voltage interstate transmission lines in the United States were installed to connect large government-built hydroelectric plants to load centers. As in China, these dams are operated to provide electricity, control flooding, and provide irrigation (BPA 2016). ${ }^{3}$ Public power entities receive nearly all of the electricity, usually delivered across transmission networks operated by federal agencies such as the Bonneville Power Administration (BPA). These wholesale power

\footnotetext{
${ }^{3}$ See also the Tennessee Valley Authority website: https://www.tva.gov/About-TVA.
} 
customers include local utilities owned and operated by a city or town, rural customer-owned electric cooperatives, and special utility districts created by local government. Hydropower deliveries to these customers are generally allocated according to law or administrative determinations. Grand Coulee Dam in the State of Washington is the largest electric generator of any type in the United States with an operating capacity of 6,765 MW. BPA's transmission network crosses eight states and serves more than 130 public power entities.

Some investor-owned utilities in the western United States built interstate transmission in the 1970s and 1980s to connect new large-scale coal plants that were sited near fuel supplies but far from major load centers. Some of these new lines passed through as many as three states.

Energy purchasers are the primary driver of whether renewable energy is transmitted across state lines., They, in turn, are influenced by state renewable energy policies and cost considerations. Renewable Portfolio Standards (RPS), which have been adopted in 29 states and place binding requirements on utilities or load-serving entities to procure RE (with penalties if they are not met), significantly impact the location of RE development and transmission needs. Utilities often seek least-cost generation to meet RPS requirements; therefore, they sometimes source from cost-effective renewable generators in surrounding states, in accordance with specific policy requirements.

RPS laws and their implementation regulations typically provide guidance on eligible renewable resources and include locational eligibility considerations. Whether the state is within a larger wholesale power market can influence geographic eligibility rules. Often, if a state is within a wholesale power market, the broader power market is defined as the area of eligibility, and eligible generation must be delivered to the broader market. For states in which electric markets have not been restructured, eligible generators are sometimes required to deliver the energy to the state, but rules vary. Locational requirements for distributed generation also typically differ but are often required to interconnect to the local grid.

Geographic sourcing requirements in state RPS policies can generally be grouped into several categories. In general, most requirements specify that renewable energy be generated within a specified state or region or delivered to a specified state or region, while some states have, or have had in the past, policy provisions to encourage in-state or in-region generation. In general, these requirements influence the inter-state transmission of RE.

Typically, RE generators have the option to sell into at least several states; however, this can be limited for generators located far from states with RPS policies. A recent analysis examined the issue of geographic sourcing to meet RPS policies from the perspective of market opportunities for RE generators. Accounting for recent changes in eligibility rules, a renewable generator located in a particular state must sell power to states or regions that comply with an RPS (Holt 2016).

Outside of RPS policies, utilities or other buyers that procure RE purely for their own purposes and without policy constraints are typically interested in procuring the least-cost RE available to meet their needs. Delivery costs factor in to how long-distance RE compares economically with local and distributed resource options. An earlier study by Hurlbut et al. (2013) examined potential markets for renewable energy in the western United States outside of RPS markets and what they might mean for transmission needs. 


\subsection{Models for Planning and Using Cross-State Transmission}

\subsubsection{Wheeling across Existing Transmission between BAs}

Wind energy can also move across states or utility service territories to supply other utilities with RE. For example, Wyoming has more than 1,400 MW of wind energy capacity installed and does not have an RPS requirement. However, it has very good wind resources and lands that are suitable for wind power development, which translates to very cost-effective wind energy generation - some of the lowest-cost wind resources in the United States. Wyoming wind energy has been transported across the existing AC transmission network to other jurisdictions as far as the Pacific Northwest. For example, Pacificorp, a utility that operates in six Western states (California, Idaho, Oregon, Utah, Washington, and Wyoming), owns nine wind farms in Wyoming and purchases the output of six additional wind farms owned by others in the same state. ${ }^{4}$ The majority of Pacificorp's customers are located on the West Coast, where aggressive RPS policies are in place. The utility transmits the wind power to various locations to meet RPS requirements in the states where it operates in compliance with geographic sourcing rules.

\subsubsection{Direct Purchase within a Multi-State RTO}

In the United States, wind generation is also commonly sold across state lines in multi-state RTOs. For example, in the PJM RTO in the Eastern United States, many states have RPS requirements with substantial targets of $20 \%$ renewables or more. This region also has several states with high population density, urban corridors, and an overall lack of cost-effective wind resources. Therefore, interstate procurement of renewable energy within the bounds of the large RTO is common, as is interstate dispatch and use of the least-cost conventional generation. Installed wind capacity in PJM is concentrated in a few states, which include Illinois, with 3,800 MW; neighboring Indiana, with 1,900 MW; and Pennsylvania, with more than 1,300 MW. ${ }^{5}$

Many of the states in PJM specify that the renewables must be delivered to PJM to be eligible to meet the RPS requirements. In addition, trade in Renewable Energy Certificates (RECs) is common across the RTO, enabling load-serving entities to procure RECs from eligible RE facilities in the region. Together, the rules regarding RE delivering to the RTO and enabling the use of RECs to meet compliance obligations have minimized the need for substantial new transmission investments in the region.

\subsubsection{HVDC "Superhighway"}

Private transmission developers in the United States have proposed building new high-voltage DC (HVDC) transmission to move wind power across several states to major load centers. These proposed lines are similar to China's long-distance, ultra-high voltage DC lines, except that they would be used primarily for large-scale wind generation. Most such projects plan one HVDC terminus in a region where wind power tends to have very high capacity factors and the other terminus in or near a major load center. Projects have been proposed to move Wyoming wind power to California, Texas wind power to Tennessee and the Southeast, and New Mexico wind power to California.

\footnotetext{
${ }^{4}$ For example, see the map of Pacificorp's wind resources at http://www.pacificorp.com/content/dam/pacificorp/doc/Efficiency_Environment/Wind_Projects_Map.pdf, accessed October 3, 2016.

${ }^{5}$ See the American Wind Energy Association wind energy database at http://www.awea.org/Resources/Content.aspx?ItemNumber=5059 .
} 
Unlike the HVAC network wheeling model described in Section 3.4.1 above), an HVDC line does not tie into any intermediate network lying between the DC terminals. Doing so would require a DC-to-AC converter station at each interconnection point, which could make the project prohibitively expensive if the intermediate network does not connect to a high-volume market. Thus, a major consideration for an HVDC line is whether markets along the route are large enough to provide a significant base of potential sales revenue.

The wind resources where the lines would begin typically have potential capacity factors of $45 \%-50 \%{ }^{6}$ (NREL 2010). In addition to generating higher amounts of electricity per megawatt of installed capacity, wind projects would tend to have lower construction costs in remote areas (ATB 2016). Land and labor costs in remote areas tend to be lower, and higher wind speeds mean that towers do not need to be as high.

Economically, evaluation of an HVDC "superhighway" rests on the cost of transmission compared to the difference in productivity between high-quality remote wind resources and lower-quality wind resources that can connect to existing transmission. Mathematically,

$$
\frac{K_{\text {remote wind }}+K_{H V D C}}{M W h_{\text {remote wind }}}<?>\frac{K_{\text {close wind }}}{M W h_{\text {close wind }}}
$$

where $K$ is the annualized project cost of remote wind, close wind, or HVDC transmission, and $M W h$ is the annual energy output from which the annualized project costs would be recovered. $K_{H V D C}$ would increase annual costs for remote wind, but the higher value for $M W h_{\text {remote wind }}$ would reduce the cost per MWh generated.

Recent analysis for an HVDC line from Wyoming to California suggests that the annualized cost of Wyoming wind power plus a new HVDC line could be lower than the cost of obtaining the same amount of electricity from new renewable resources located in California. The difference is even larger if bringing in wind power from Wyoming eliminates the need for transmission in California that would be needed to connect more in-state renewables to the California grid (Corbus et al. 2014).

Obstacles to approval for an HVDC superhighway have included the lack of direct benefits to states along the path of the line where there would be no power exchanges and a political preference for local resources even if the cost were higher.

\subsection{Local Protectionism Concerns}

Local protectionism has been a concern in the design of policy provisions for geographic sourcing of renewables. States have been subject to lawsuits claiming undue discrimination with respect to in-state sourcing requirements or policies to encourage in-state renewable energy generation (e.g., multipliers that credit in-state renewable generation at higher levels than other generation). Some states have changed geographic sourcing requirements in Renewable Portfolio Standard policies over time, due, in part, to these considerations.

\footnotetext{
${ }^{6}$ That is, the energy production from one MW of capacity would be 3,900 MWh to 4,400 MWh per year.
} 
In the United States, interstate commerce is guided by the Commerce Clause of the U.S. Constitution, which gives Congress the authority to regulate commerce across states. The commerce clause also prohibits states from practicing economic protectionism and unduly restricting interstate commerce. It ensures that states do not develop policies to benefit in-state interests while placing undue burdens on competitors that are out of state (Elefant and Holt 2011).

States have used a variety of approaches to encourage local generation; some of those appear to be more likely to resist legal challenges under the commerce clause. For example, some RPS laws specify that it must be possible to deliver the energy from an eligible project to customers in the state. Such delivery requirements, particularly regional requirements, are more likely to withstand challenges than in-state or location-based requirements (Elefant and Holt 2011). In addition, policy provisions encouraging distributed generation may be more defensible if the requirements are based in neutral terms, such as if they are based on interconnection requirements rather than requiring in-state installations per se, which may ultimately have the same effect (Elefant and Holt 2011). Provisions in RPS policies that encourage in-state sourcing have been challenged in some cases and may be vulnerable unless states can demonstrate legally acceptable goals for such provisions. For example, legally acceptable goals for states can include environmental protection, electricity reliability, energy conservation, safety, or resource diversity, which can be weighed against the impact on commerce (Elefant and Holt 2011).

\section{Summary}

The United States has several models for interstate transmission planning, power exchange scheduling, and pricing that vary by region. All rely to some extent on price-based economic dispatch to schedule generation, while transmission planning focuses on the infrastructure upgrades that will facilitate the most economically efficient generator dispatch. The growth of renewable energy - especially large-scale wind power - has worked in accordance with these diverse existing arrangements.

RTOs represent the most finely tuned approach to an inter-state market, and they tend to result in the greatest economic efficiency of operations. In the United States, these integrated markets often cross state boundaries, so there is no distinction between in-state load and out-of-state load within the RTO. This allows infrastructure and operational savings to be shared. Unit commitment and scheduling are done one day in advance. Dispatch is based on economic selection - for each hour in the day-ahead scheduling market, and every five minutes in the realtime balancing market. This approach achieves the objective of meeting reliability standards and serving demand at the lower possible cost. ${ }^{7}$ As the costs of wind power and solar power have come down, the economic dispatch conducted by an RTO provides clear price signals for transmission upgrades to reduce curtailment. Because the entire RTO operates as a single market, buyers can often choose from among many generators when seeking to procure power directly.

At the other end of the spectrum are transfers between states that operate as economically independent balancing areas, similar to the inter-provincial direct trading China is promoting

\footnotetext{
${ }^{7}$ Subject to various transmission and operational constraints.
} 
now. These are slower-moving markets where exchanges of generation are negotiated bilaterally. While scheduling and dispatch are not as finely tuned as they are in RTOs, individual buyers still seek purchases at the lowest cost. For renewables, this often means wheeling power from a state with excellent natural resources (e.g., wind, solar, or hydropower) across the transmission grid to another state with a large load. These point-to-point transactions are accounted separately from network load within the balancing area, although they occur on the same physical transmission system. This between-area approach allows for more administrative oversight, but it could be economically inefficient and could result in higher costs for end users.

In both cases, the cost of transmission service is accounted for separately from the cost of energy and congestion. Transmission costs are seldom or never negotiated. Instead, competition takes place with respect to the cost of energy, including the cost of managing congestion by changing unit dispatch. Once purchases and schedules are decided based on the cost of energy, transmission fees are added automatically based on the prevailing transmission tariff.

China and the United States have encountered similar issues with respect to strategic interprovincial and interstate transmission planning for renewables. Among these common issues are how to balance preferences for local energy development with what costs less for customers; how to ration available transmission capacity among different types of resources; and how to recover the cost of transmission investments. In the United States, the transition has been toward market-based mechanisms that operate impartially within the bounds of federal and state policy directives. These market mechanisms focus on energy bidding rather than on bidding for transmission. If China considers a similar path, it may investigate the value of the following options: wide adoption of economic decision-making throughout the planning and operation of the power system; and moving towards more regional coordination in planning and operations, which could involve having the existing grid companies taking on some of the appropriate roles of RTOs such as operating the transmission system, hosting the electricity market, conducting SCUC/SCED, and maintaining balance. 


\section{Appendix: RTO Case Study of Midcontinent Independent System Operator}

The Midcontinent Independent System Operator (MISO) is an RTO that covers a large part of the central United States, where much of the country's best wind resources are located. The map in Figure 2 shows the MISO service area, along with existing U.S. wind development. Within MISO, wind development is concentrated primarily in five states (Iowa, Minnesota, Illinois, North Dakota, and Michigan), while the transmission network includes some or all of 15 states.

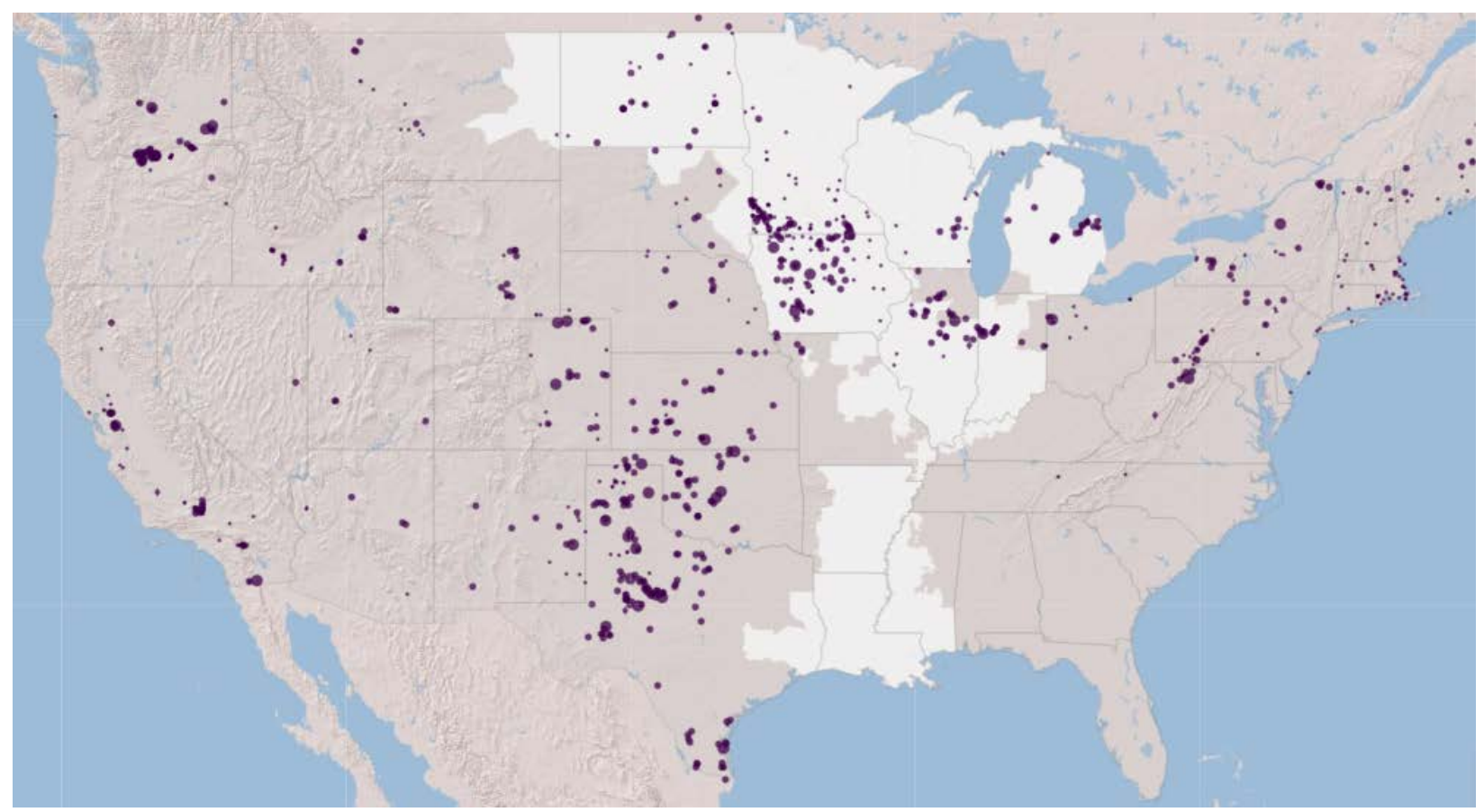

Figure 2. MISO (unshaded area) and U.S. wind development

Sources: SNL Energy, ESRI

As an RTO, MISO integrates resource plans ahead of time, maintains load-interchangegeneration-balance within a balancing authority area, and supports interconnection frequency in real-time. This means that the balance of energy supply and demand must be maintained on the electric transmission system in real-time.

The balance takes into account not only the generation and load within the MISO footprint, but also the interchange of power between the MISO and other neighboring RTOs, such as PJM, and other non-RTO neighbors such as Tennessee Valley Authority and Southern Company Services (SOCO). In this section, we will introduce the transmission-scheduling process in the day-ahead and real-time operation timescale for MISO, including both inter- and intra-RTO transmissions. The transmission-scheduling process for other RTOs such as ISO New England and PJM may be slightly different.

Transmission schedules are a plan to move energy from one location to another, across transmission lines. A transmission schedule is generally created from an e-tag, which is a unique identification tag created by market participants and submitted to MISO. A high-level 
transmission-scheduling process is shown in Figure 3. The market participants can reserve transmission service on the transmission lines to facilitate the flow of power for their schedules. E-tags are created to allow for full tracking of planned power flows from end to end. The physical scheduling system (PSS) receives all tagged transactions and approves valid transactions. The approved transactions are then sent to the dispatch engine to generate actual dispatch instructions in the market.

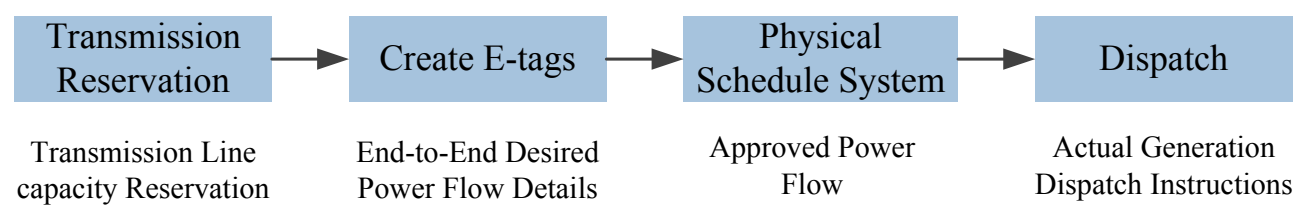

Figure 3. Transmission scheduling process

In MISO, the bilateral transactions are contracts between parties for the transfer of and financial responsibility for energy, from suppliers to consumers. There are two forms of bilateral transactions: (1) financial schedules, which transfer financial responsibility within and across the market footprint, and (2) interchange schedules, which transfer physical energy into, out of, within, and through the MISO market footprint. The process of interchange schedules is described below.

An interchange schedule is submitted via an e-tag by a purchase-selling entity representing withdrawals and injections at specified locations. All interchange schedules specify (MISO 2015) the following:

- Point-of-receipt (POR)

- Point-of-delivery (POD)

- Source point

- Sink point

- Megawatt (MW) quantity

- Applicable time period

- Transaction type and energy types with the OASIS product that can be used for each transaction type

- Market transaction and the interface node that is sent to a dispatch engine for market calculation

- The interface node or nodes that are sent to market settlements for settlement calculations.

There are four different types of interchange schedules, shown in Figure 4 [MISO 2011]:

1. "Import" schedule, where the source point is external to the MISO market footprint and the sink point is internal 
2. "Export" schedule, where the sink point is external to the MISO Market footprint and the source point is internal

3. "Through" schedule, where the source point and sink point are external to the MISO market footprint

4. "Within" schedule (for grandfathered agreements), ${ }^{8}$ where the source point and sink point are internal to the MISO market footprint.

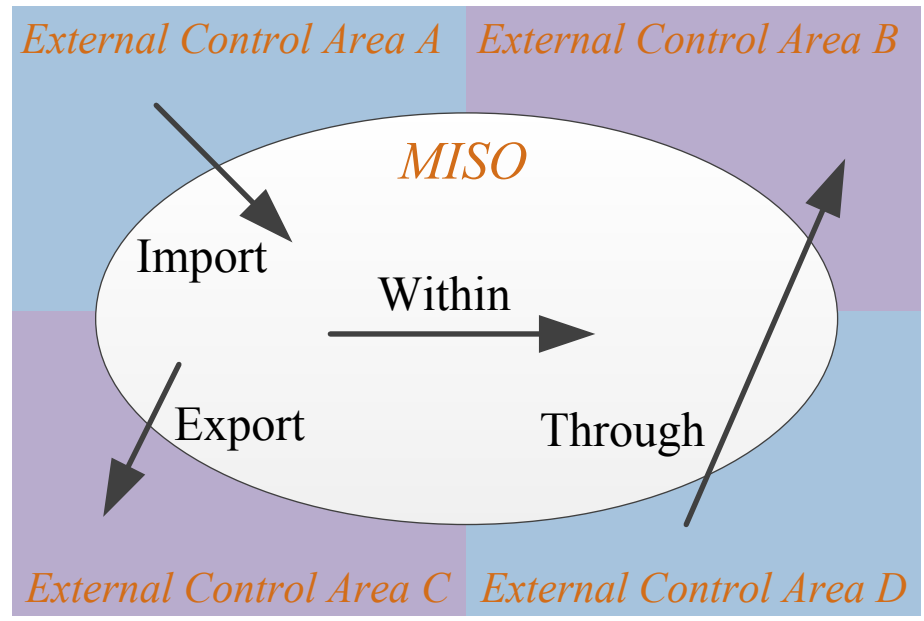

Figure 4. Different types of interchange schedules in MISO

\section{How Transmission Scheduling Addresses RE}

Wind represents the most abundant clean energy fuel source in MISO. The footprint of MISO also includes biomass power - the use of animal waste or plant matter to generate electricity — as well as hydropower. MISO works with stakeholders to provide equitable solutions for tapping into renewable energy-rich regions and creating opportunities for everyone to benefit from the use of clean energy resources.

The transmission scheduling process at MISO is used for all types of generation resources, including RE resources. Once the physical schedules are approved (see Figure 2), RE resources will be dispatched along with all other generation resources within the MISO market footprint. Note that MISO does not have particular transmission scheduling rules for RE resources, because all resources should follow the same rules. Most of MISO's wind resource is registered as dispatchable intermittent resources (DIRs), and only a small portion is registered as non-DIR. RE resources are eligible to supply energy but not operating reserves (including regulating, spinning, or supplemental reserves). In the day-ahead market, DIRs demonstrate the same market behaviors as traditional generation. All the generators, including DIRs, should cover the parameters below in the DA market, including energy offer $(\$ / M W)$, ramp rate $(\mathrm{MW} / \mathrm{min})$,

\footnotetext{
${ }^{8}$ The "within" schedule is listed as the interchange schedule because the Federal Energy Regulatory Commission determined that certain grandfathered transactions would be carved out of the MISO market. These transactions must be tagged to MISO as the balancing authority for the generation control area (GCA) and/or load control area (LCA) and provide a grandfathered transmission service reservation. Within schedules must be accompanied by transmission service provided according to the terms of a grandfathered agreement or MISO network service, or may be accompanied by confirmed reservations of point-to-point transmission service.
} 
commit status and costs, and min and max limits (MW). In real-time, DIRs are different from traditional generations in that DIRs use 5-minute power forecasting as the maximum generation limit, while traditional generations use an hourly submitted limit. The detailed rules used to determine the maximum limit for each DIR and each real-time interval is as follows:

- If market participants submit wind power forecasts in this interval, the maximum limit of energy output equals the forecasted power submitted by the participant.

- If market participants did not submit wind power forecasts, and MISO provided the forecast, then the MISO forecast will be used as the maximum limit. ${ }^{9}$

- If neither the market participant nor the MISO provides the forecast, the state estimator value will be used.

A detailed comparison of real-time market parameters among traditional generation, $\mathrm{RE}$ resources as non-DIR, and RE as DIR is shown in Table 4 (MISO Workshop 2011).

Table 4. Real-Time Market Resource Comparison

\begin{tabular}{llll}
\hline $\begin{array}{l}\text { Market Operation } \\
\text { Parameters }\end{array}$ & Traditional Generation & $\begin{array}{l}\text { Renewable Energy } \\
\text { Resources as Non- } \\
\text { DIR }\end{array}$ & $\begin{array}{l}\text { Renewable Energy } \\
\text { Resources as DIR }\end{array}$ \\
\hline Offers & $\begin{array}{l}\text { Energy and Operating } \\
\text { Reserve Offers }\end{array}$ & No Offers & Energy Offers Only \\
\hline Ramp rates & Ramp Rates & No Ramp Rates & Ramp Rates \\
\hline Limits & $\begin{array}{l}\text { Hourly Max and Min } \\
\text { Limits }\end{array}$ & $\begin{array}{l}\text { No Limits (use State } \\
\text { Estimation Data) }\end{array}$ & $\begin{array}{l}\text { Hourly Min Limit } \\
\text { 5-Min Forecast Max } \\
\text { Limit }\end{array}$ \\
\hline Marginal & Can be Marginal & Cannot be Marginal & Can be marginal \\
\hline Dispatchable & Yes & No (Manual Only) & Yes \\
\hline
\end{tabular}

\section{Transmission Pricing and Cost Recovery within MISO}

In an RTO with multiple balancing areas like MISO, there are two distinct settlement processes $\left(\right.$ MISO 2016) ${ }^{10}$ :

- Market Settlements - The market settlements process financially settles competitive transactional activities by and between market participants within the RTO's managed transmission system. All energy dispatch is charged and paid in market settlements.

- Transmission Settlements - The transmission settlements process financially settles transmission customers' use of MISO's transmission system and mandated, noncompetitive ancillary services on a monthly calendar basis. Customer charges for

\footnotetext{
${ }^{9}$ MISO has detailed wind power forecasting for each specific wind farm for each 5-min interval in its footprint (data bought from a vendor). If market participants submit their own forecast data, the MISO data will not be used. If market participants do not submit their own forecast data (this happens quite often), the MISO data will be used.

${ }^{10}$ It should be noted that the content in this section is summarized from MISO. Rules and policies on other RTOs might be slight different.
} 
transmission and ancillary services are collected and distributed to the transmission owners and the providers of the mandated ancillary services.

The market settlement process will determine the day-ahead (hourly) and real-time (5-minutes) LMP at each node of the system. LMP takes into account the effect of actual operating conditions on the transmission system in determining the price of electricity at different locations in the RTO region. The transmission settlement process will determine what charges transmission customers incur and the revenue that must be distributed to transmission owners and/or generation owners on a calendar month billing cycle. The RTO internal point-to-point transmission service charge is calculated as follows (MISO 2016):

\section{Charge $_{P T P}=R C_{P T P} \times E R_{S 1} \times$ Increment}

where Charge $_{P T P}$ is the charge of point-to-point transmission service in U.S. dollars $(\$) . R C_{P T P}$ is reserved capacity for each profile segment of the point-to-point reservation in MW. $E R_{S I}$ is the effective zonal rate included in the OASIS reservation profile segment in $\$ / \mathrm{MW}$. It is calculated based on some rules as shown in MISO's tariff and approved by FERC. Increment is the duration of a reservation prorated to the billing cycle based on the appropriate product type. For example, for a weekly reservation for a two-week period, $\mathrm{ER}_{\mathrm{S} 1}$ would be the weekly rate and the increment would be 2 .

\section{Transmission Flows from MISO to another RTO or BA}

As shown in Figure 4, there are three types of interchange schedules between and among RTOs: import schedule, export schedule, and through schedule. Market participants can select from several types of schedules (MISO 2015), including those described in the following sections.

\section{Fixed Interchange Schedules}

Fixed interchange schedules are physical transactions that bring energy to and from the RTO at the external interfaces. Market participants can use fixed interchange schedules to deliver energy into, out of, or through the energy and operating reserve markets. Market participants submitting this type of transaction to the RTO are "price takers" for that energy, which means they are willing to accept any price that clears the market as long as they are dispatched. All fixed interchange schedules' energy prices are settled at the LMP for the applicable energy and operating reserve market for the appropriate external interface physical nodes.

\section{Dispatchable Interchange Schedules}

Dispatchable interchange schedules are physical transactions that specify a bid or offer in \$/MWh. Dispatchable interchange schedules are supported in the day-ahead energy and operating reserve market only, and are qualified only for import and export schedules. They are not valid for through or within schedules. Prices determined in the day-ahead energy and operating reserve market at the appropriate external interface physical nodes. Dispatchable pricing per $\mathrm{MWh}$ has a minimum of $\$ 0$ and a maximum of $\$ 1000$ for import schedules and a minimum of $\$ 0$ and a maximum of $\$ 9999.99$ for exports. Only one price pair per hour is allowed, and partial hour pricing is not permitted. The price limits are determined by MISO stakeholders, and may differ in other RTOs. Pricing information must be the same on multi-day e-tags. 


\section{Up-to-Transmission Usage Charge (TUC) Interchange Schedules}

Up-to-TUC interchange schedules are physical transactions that indicate a willingness to pay the TUC (in $\$ / M W h$ ), represented by a maximum amount beyond which the market participant agrees to curtail. TUC is a charge attributable to the increased cost of energy delivered at a given Commercial Node when the Transmission System is operating under constrained conditions or due to losses on the system. The TUC is equal to the difference in the LMP at the sink and the LMP at the source. For example, a market participant selects this transaction type may specify the willingness to pay the TUC amount to be $\$ 15 / \mathrm{MWh}$. If the LMP difference between the sink and source nodes is greater than $\$ 15 / \mathrm{MWh}$, the schedule will be curtailed. Note that market participants can specify any amount of TUC they are willing to pay up to $\$ 25 / \mathrm{MWh}$ (this value is determined in the MISO Tariff). Up-to-TUC interchange schedules are valid for day-ahead markets only. The cleared amount determined in the DA is rolled into the real-time (RT). The TUC is calculated based on the differences in LMPs between the source points and sink points.

A comparison of the three types of schedules is shown in Table 5.

Table 5. Comparison of the Three Types of Schedules

\begin{tabular}{llll}
\hline $\begin{array}{l}\text { Interchange } \\
\text { Schedule } \\
\text { Type }\end{array}$ & Key Features & $\begin{array}{l}\text { DA or RT } \\
\text { Market }\end{array}$ & Settlement \\
\hline $\begin{array}{l}\text { Fixed } \\
\text { interchange }\end{array}$ & $\begin{array}{l}\text { The market participant would like to } \\
\text { schedule a certain amount (MWs) of } \\
\text { interchange at whatever price (i.e., } \\
\text { price taker). }\end{array}$ & $\begin{array}{l}\text { Both DA } \\
\text { and RT }\end{array}$ & $\begin{array}{l}\text { Similar to the "must-run" } \\
\text { concept; the schedules are } \\
\text { settled for the LMP at } \\
\text { appropriate interfaces. }\end{array}$ \\
\hline $\begin{array}{l}\text { Dispatchable } \\
\text { interchange }\end{array}$ & $\begin{array}{l}\text { A market participant can submit the } \\
\text { bid/offer to compete with other } \\
\text { market participants to win the } \\
\text { transmission schedule. }\end{array}$ & DA Only & $\begin{array}{l}\text { The price for the schedule is } \\
\text { determined by DA LMPs at } \\
\text { appropriate interfaces. }\end{array}$ \\
\hline Up-to-TUC & $\begin{array}{l}\text { If the price difference between sink } \\
\text { and source nodes is higher than the } \\
\text { willingness to pay the TUC, the } \\
\text { schedule is curtailed. }\end{array}$ & DA Only & $\begin{array}{l}\text { The price for the schedule is } \\
\text { determined by DA LMPs at } \\
\text { appropriate interfaces. }\end{array}$ \\
\hline
\end{tabular}




\section{References and Additional Sources}

Bai, Shunmin, Dingyi Liu, Ze Ye, and Fei Wang. 2016. "Inter-Provincial Inter-Regional Direct Trading Reform Discussion." China Power Enterprise Management 1:64-67.

Bonneville Power Administration. 2016. BPA Facts. https://www.bpa.gov/news/pubs/ GeneralPublications/gi-BPA-Facts.pdf.

Caixin Energy. 2016. "Inter-Regional Electricity Trading Exchange Opened, Is It A Curse or A Blessing For Renewable Energy?" Caixin Energy. Accessed August 26, 2016. http://www.wusuobuneng.com/archives/28978.

Central China Electricity Regulatory Bureau of National Energy Administration. 2014. Central China Regional Electricity Trading and Market Monitoring Report. Wuhan, Hubei: Central China Electricity Regulatory Bureau.

Cheung, Kat. 2011. Integration of Renewables: Status and Challenges in China. Paris: International Energy Agency. https://www.iea.org/publications/freepublications/publication/ Integration_of_Renewables.pdf.

China Power. "Ten Year Summary: Power Market Reform: Direct Trading.” Accessed August 19, 2016. http://www.chinapower.com.cn/information\&yjbg/20160106/8378.html.

CNKI. 2016. China Electricity Industry and Economy Social Development Statistical Database. CPIA (China Photovoltaic Industry Association). 2016. 2015-2016 China Solar PV Industry Annual Report. Beijing: CPIA.

Cochran, Jaquelin, Mackay Miller, Owen Zinaman, Michael Milligan, Doug Arent, Bryan Palmintier, Mark O’Malley, Simon Mueller, Eamonn Lannoye, Aidan Tuohy, Ben Kujala, Morten Sommer, Hannele Holttinen, Juha Kiviluoma, and S.K. Soonee. 2014. Flexibility in $21^{\text {st }}$ Century Power Systems. Golden, CO: National Renewable Energy Laboratory. NREL/TP-6A2061721. http://www.nrel.gov/docs/fy14osti/61721.pdf.

Corbus, D., D. Hurlbut, P. Schwabe, E. Ibanez, M. Milligan, G. Brinkman, A. Paduru, V. Diakov, and M. Hand. 2014. California-Wyoming Grid Integration Study, Phase 1-Economic Analysis. Golden, CO: National Renewable Energy Laboratory. NREL/TP-6A2061192. http://www.nrel.gov/docs/fy14osti/61192.pdf.

CSER (Public Policy Research Institute of China Society of Economic Reform). 2012. Transaction and Pricing Mechanisms for Cross-Regional (Province) Delivery of Large-Scale Renewables. Beijing: The Energy Foundation.

CWEA (China Wind Energy Association). 2016. 2015 China Wind Installed Capacity Statistical Brief. Beijing: CWEA.

Eastern China Grid Company. 2016. Eastern China Grid Electricity Market Trading Information Report. Shanghai: Eastern China Grid Company. 
Elefant, Carolyn, and Edward A. Holt. 2011. The Commerce Clause and Implications for State Renewable Portfolio Standard Programs, Prepared for the RPS Collaborative under contract with the Clean Energy States Alliance. http://cesa.org/assets/Uploads/CEG-Commerce-Clause-paper031111-Final.pdf.

ERCOT (Electric Reliability Council of Texas). 2016. ERCOT Nodal Protocols. Section 6: Adjustment Period and Real-Time Operations. Section 7: Congestion Revenue Rights. http://www.ercot.com/mktrules/nprotocols/current.

FERC (Federal Energy Regulatory Commission). 2007. Preventing Undue Discrimination and Preference in Transmission Service. Final Rule (Order 890).

Global Energy Interconnection Development and Cooperation Organization. 2016. "UHV Grid." Beijing: GEICO. Accessed October 17, 2016. http://www.geidco.org/html/qqnycoen/col2015100800/column_2015100800_1.html.

Holt, Ed 2016. Potential RPS Markets for Renewable Energy Generators. Prepared for the RPS Collaborative under contract with the Clean Energy States Alliance. http://www.cesa.org/assets/2014-Files/Potential-RPS-Markets-Report-Holt-January2014.pdf

Hurlbut, David J., Joyce McLaren, and Rachel Gelman. 2013. Beyond Renewable Portfolio Standards: An Assessment of the Regional Supply and Demand Conditions Affecting the Future of Renewable Energy in the West. NREL/TP-6A2057830. http://www.nrel.gov/docs/fy13osti/57830-1.pdf.

Hurlbut, David, Ella Zhou, Kevin Porter, and Douglas J. Arent. 2015. Renewables-Friendly' Grid Development Strategies: Experience in the United States, Potential Lessons for China. Golden, CO: National Renewable Energy Laboratory. NREL/TP-6A2064940. http://www.nrel.gov/docs/fy16osti/64940.pdf.

IRENA (International Renewable Energy Agency). 2014. Renewable Energy Prospects: China. Abu Dhabi: IRENA. http://irena.org/remap/IRENA_REmap_China_report_2014.pdf.

Kahrl, Fredrich, and Xuan, Wang. 2015. Integrating Renewables Into Power Systems in China: A Technical Primer: Electricity Planning. Beijing, China: Regulatory Assistance Project. http://www.raponline.org/wp-content/uploads/2016/05/rap-e3-chinaelectricityplanning2015-oct.pdf.

Liu, Jun. 2016. Production Simulation of Renewable Energy Integration: How to Reduce Curtailment. Presentation by Jun Liu, State Grid Energy Research Institute, at the National Renewable Energy Laboratory, September 22, 2016.

Milligan, Michael, Bethany Frew, Ella Zhou, and Douglas J. Arent. 2015. Advancing System Flexibility for High Penetration Renewable Integration. Golden, CO: National Renewable Energy Laboratory. NREL/TP-6A20-64864. http://www.nrel.gov/docs/fy16osti/64864.pdf. 
MISO (Midcontinent Independent System Operator). 2011. Dispatchable Intermittent Resource (DIR) Workshop. April 13,

2011. https://www.misoenergy.org/Library/Repository/Meeting\%20Material/Stakeholder/Works hops\%20and\%20Special\%20Meetings/2011/DIR\%20Workshops/20110413\%20DIR\%20Implem entation $\% 20$ Workshop $\% 20$ Presentation.pdf.

- 2011. Physical Scheduling at MISO Market. October

2011. https://www.misoenergy.org/Library/Repository/Meeting\%20Material/Stakeholder/Trainin g\%20Materials/MP\%20100/Physical\%20Scheduling.pdf.

_. 2015. Business Practice Manual: Physical Scheduling. Effective Date: SEP-01-2015.

_ 2016. Business Practice Manual: Transmission Settlements. Effective Date: JAN-012016.

MOF (Ministry of Finance of the People's Republic of China). 2014. "Current Tax Split Financial System Framework.” Beijing: MOF. Accessed October 12, 2016. http://www.mof.gov.cn/zhuantihuigu/czjbqk1/jbqk2/201405/t20140504_1074657.htm.

NDRC (National Development and Reform Commission). 2015. Notice on Improving InterRegional/Provincial Electricity Trading Price-Formation Mechanism and Related Issues. Beijing: NDRC.

- 2015. "Several Opinions from CCP State Council on Deepening Power Sector Reform [2015] No. 9." Beijing: NDRC. http://tgs.ndrc.gov.cn/zywj/201601/t20160129 773852.html.

2016. "NDRC Reply Regarding Partially Open Up Yindong HVDC Inter-Regional Transmission Scheduling." Beijing:

NDRC. http://www.sdpc.gov.cn/gzdt/201603/t20160309 792400.html.

NEA (National Energy Administration). 2010. "Inter-Provincial and Inter-Regional Power Trading and Market Monitoring Study.” Accessed August 19, 2016. http://henb.nea.gov.cn/html/2010/1529.htm

- 2014. "Monitoring Report of the Electricity Trading Order at Central China Post." Beijing: NEA. http://news.bjx.com.cn/html/20140627/522537-2.shtml.

- 2015a. 2011-2013 National Inter-Regional and Inter-Provincial Transmission Line Loss Information Report. Beijing: NEA.

_. 2016a. "2015 Solar PV Generation Statistics.” Beijing:

NEA. http://www.nea.gov.cn/2016-02/05/c 135076636.htm.

- 2016b. "2015 National Electricity Dispatch, Trading, and Market Monitoring Report." Beijing: NEA. http://zfxxgk.nea.gov.cn/auto92/201606/t20160614 2265.htm.

- 2016c. “2016 Wind Industry Development.” Beijing:

NEA. http://www.nea.gov.cn/2016-02/02/c 135066586.htm. 
- 2016d. "NEA Notice on Promulgating Electric Power Planning Management Measures." Beijing: NEA. http://zfxxgk.nea.gov.cn/auto84/201606/t20160606_2258.htm.

2016e. "Jinsu HVDC and Eight Typical Grid Projects Investment Performance Monitoring Report." Beijing:

NEA. http://zfxxgk.nea.gov.cn/auto92/201608/t20160801 2281.htm.

—. 2016f. "2015 National Electricity Price Information Monitoring Report.” Beijing:

NEA. http://zfxxgk.nea.gov.cn/auto92/201611/t20161101_2312.htm.

NEA, and Ministry of Industry and Information Technology (MIIT). 2013. "Notice on Standardizing the Direct Trading between Electricity Consumers and Generation Companies." Beijing: NEA and MITT. http://zfxxgk.nea.gov.cn/auto92/201310/t20131030_1716.htm.

NERC (North American Electricity Reliability Corporation). 2016. Glossary of Terms Used in NERC Reliability

Standards. http://www.nerc.com/pa/stand/glossary $\% 200 \mathrm{of} \% 20$ terms/glossary_of terms.pdf.

Ni, Ming, and Zhixin Yang. 2012. "By Leaps and Bounds: Lessons Learned from Renewable Energy Growth in China." IEEE Power \& Energy Magazine (March/April 2012):3743. http://magazine.ieee-pes.org/files/2012/02/10mpe02-ni-2178294-x.pdf.

NREL (National Renewable Energy Laboratory). 2016. Annual Technology Baseline and Standard Scenarios. Spreadsheet and presentation. http://www.nrel.gov/analysis/data tech_baseline.html.

NREL, AWS Truepower. 2010. "Utility-Scale Land-Based 80-Meter Wind Maps.” http://apps2.eere.energy.gov/wind/windexchange/wind_maps.asp.

PJM. 2010. Open Access Transmission Tariff. FERC Docket No. ER10-2710000. http://www.pjm.com/media/documents/merged-tariffs/oatt.pdf.

—. 2016. "Financial Transmission Rights FAQs." http://learn.pjm.com/threepriorities/buying-and-selling-energy/ftr-faqs.aspx.

RAP (Regulatory Assistance Project). 2016. China On-Grid Tariff Mechanism Reform Research. Beijing: RAP. http://www.raponline.org/wpcontent/uploads/2016/05/generationdispatchcompensationreform-cn-2016-mar.pdf.

SGCC (State Grid Corporation of China). 2016a. State Grid Corporation of China 2015 Annual Electric Power Market Trading Information Report. Beijing: SGCC.

- 2016b. State Grid Corporation of China Promoting New Energy Development White Paper (2016). Beijing:

SGCC. http://www.cma.gov.cn/2011xwzx/2011xmtji/201603/t20160313 306329.html.

SERC (State Electricity Regulatory Commission). 2011. 2010 National Electricity Trading and Market Monitoring Report. Beijing: SERC. 
-2005. Order of the State Electricity Regulatory Commission (No. 14) Provisions on the Information Disclosure of Electric Power Enterprises. Beijing: SERC.

South China Morning Post. 2016. "China Completes First Cross-Provincial Electricity Direct Trading, Price Drop by about 10\%.” August 29.

State Council. 2013." State Council Decision on Cancelling and Delegating the Administrative Approval of Projects and Other Matters." Beijing: State Council of People's Republic of China. http://www.gov.cn/zwgk/2013-05/15/content_2403676.htm.

TETCO v. FERC (Texas Eastern Transmission Corporation v. Federal Energy Regulatory Commission). 1996. United States Court of Appeals, Fifth Circuit. Dec. 30.

Wang, Xuhui. 2016. "Consensus Reached that Wind Project Establishment Should Be Aligned with Grid Planning." China Energy. Accessed September 30, 2016. http://www.cnenergy.org/dl/dw/201603/t20160329_276363.html.

Wen, Huawei. 2016. "Northwest Power Market Knocking on Doors." Southern Power Observer. July 20, 2016. http://chuansong.me/n/449085941435.

Wiser, Ryan, and Galen Barbose. 2008. Renewable Portfolio Standards in the United States: A Status Report with Data through 2007. Lawrence Berkeley National Laboratory. LBNL154E. https://emp.lbl.gov/sites/all/files/REPORT\%20lbnl-154e-revised.pdf

Yang, Yang. 2016. "Four Regional Grid Companies Have Been Deregistered, Used to Be Products of 2002 Power Sector Reform." The Paper. Accessed August 30, 2016. http://www.thepaper.cn/newsDetail_forward_1502725. 